\title{
INTERDIMENSIONAL TRADE BENEFITS
}

\section{A powerful argument for cooperation.}

\section{BY BRIAN TRENT}

C $T$ t was a missile," she explained. The admirals of the Brightworld Imperium blinked from where they sat around the crisis room. "What do you mean?" one of them said at last. "A missile? From where? From whom?"

Dr Harshadi Hennig stood at the centre of the rounded chamber, feeling less like a scientist giving a presentation and more like a condemned prisoner. She raised her hologloves, conjuring an image of Eris Station orbiting Neptune's serene planetscape.

"This is a recording from an approaching shuttle," Hennig said.

The Neptunian station was a grey wheel against the void. The time index ticked away until - at the 18:43:30 mark - a greenish light split the blackness. It seemed as though a massive Venetian blind was opening, an emerald sky materializing against cold space. A colossal, spire-like shape appeared. Then the light blinked out, the odd shape disappearing with it. The shuttlecam trembled in aftershock. The orbital station was -

"Gone," one of the admirals snapped in the impatient tone used for all plebeians of the Empire. "Yes, Dr Hennig, we know this. Tell us what the devil happened to Eris Station!"

She bowed obediently. "Of course, Admiral. The station was destroyed by a missile fired from another dimension."

"It ... what?"

"A missile. Not fired by insurrectionists or terrorists, but from a universe next door."

She conjured a still-frame of the greenish rupture with her gloves.

"It appears," she continued, "that the multiverse theory is correct. This video shows the splitting of a dimensional membrane, and the brief materialization of what we believe is the alien equivalent of an ICBM."

The admiralty board conferred with each other. "Are you saying that multidimensional aliens attacked us?" one cried.

"Well ... not exactly." She clapped her hands and the hologram vanished. "If not for this lucky recording, we'd never have known. You see, this wasn't an attack. Frankly, our extraterrestrial neighbours didn't know life occupied this side of the membrane at all."

"Dr Hennig, you're not making any sense -"

"What we saw," the scientist dared interrupt, "was an interdimensional weapon test."

Again, a deadly silence filled the chamber. "Explain," someone managed.
"I'm not sure how much I can explain. Like us, these aliens are involved in an arms race. Like us, they're always experimenting with bigger and better technology. Build a bomb, your enemies build a shield. So you build a better bomb. What we just witnessed ..."

"Yes?"

“... was the test of an extradimensional missile. Put simply, it's a missile that winds up into a higher dimension - our dimension - and is then fired back into their dimension, in order to achieve extraordinary hypervelocities. Imagine having a fist-fight a few feet underwater. You're limited in how much power you can pack into a punch. But if you draw your fist through the air above..."

She flexed her gloved fingers again, replaying the holo to a molasses-like crawl. The freakish alien missile appeared, and was gone in a blink. Eris Station was pulled in after it, like debris sucked into an undertow.

"That's what happened to Eris Station," Hennig said decisively. "It got pulled into a neighbouring dimension along with the missile."

She noticed a new expression washing through the admiralty board. Excitement.

"Tell us more ..." one said, practically licking his lips.

"Certainly, sir. The test resulted in the deaths of millions of our alien neighbours."

"No doubt. Looks like a badass missile."

"No, sir, you misunderstand. The missile detonation was fierce, yes, but it was a localized event. The alien test inadvertently caused a virulent epidemic that spread through half a continent." She regarded her audience's perplexed faces. "Because when the people of Eris Station were sucked into the interdimensional wake, their organic matter caused a deadly epidemic in the universe next door. Put simply, the aliens wanted a fast missile and ended up creating a bioweapon."

"Will this ... happen again?"

"It's been happening, all over the Solar System. Brief flashes of light. Navigator reports of odd, transitory shapes glimpsed in space. But the aliens haven't been able to achieve the original results, because they aren't accidentally sweeping up human beings with their subsequent tests. Unfortunately, in their determination to recreate the effects, they've been increasing their tests. It's only a matter of time before a dimensionally spun-up missile materializes in the same space as a planet."

The admirals looked stricken.

"Don't worry," Hennig said.

"Don't worry?" an admiral mocked. "This stupid pleb has discovered a threat to the Imperium and she's telling us not to worry!"

"Perhaps she's found a way to neutralize this threat?" another suggested.

"Neutralize?" Hennig scratched her head. "Not exactly. You see, over the past few weeks I managed to establish contact with our interdimensional neighbours. Oh, it took a while, but we worked out a rudimentary form of communication. Surprised the hell out of them ... but it's been productive, after a fashion."

"Wait, you initiated communication with a foreign power - "

"We made a deal," she spoke over the admiral. "They agreed to stop blindly testing their missiles in our dimension. In return ..." She smiled. "We give them coordinates for where they should be testing their missiles."

She saw the realization kindle in their eyes. Or maybe, she thought, that was just the kindling of greenish light suddenly appearing around them.

The admiralty board leapt to their feet.

"We plebs are tired of being slaves to the Imperium," Hennig had to shout above the escalating sound. "So we sent the aliens coordinates of your military bases. The aliens get their bioweapons, and we get to be free of you. Everyone wins!"

One of the admirals screamed in the intensifying light. "You'll die too!"

Hennig looked puzzled. "Me? Oh ... I'm not even here."

She clapped her gloves, and her hologram vanished.

Brian Trent's speculative fiction appears regularly in ANALOG, Fantasy \& Science Fiction, COSMOS, Galaxy's Edge and numerous year's best anthologies. His website is www.briantrent.com. 